\title{
Can Ireland's emigration past inform the
}

\section{incorporation of its immigrant}

\section{population in the future?}

Irial Glynn

Irial Glynn is a postdoctoral researcher for the 'Emigre' project examining contemporary Irish emigration, which is attached to the Department of Geography and the Institute for Social Sciences in the 21st Century at University College Cork

No other European country has experienced such high and sustained levels of emigration per capita over the past two centuries as Ireland, with over 10 million having left the island between 1800 and 2000. Since the late 1990s and especially after the expansion of the EU in 2004, Ireland has received an unprecedented number of immigrants. According to the 2011 census, almost 17 percent of the Republic of Ireland's population was born outside the state and over 12 percent held a different nationality. Thus far, the Irish state has taken a laissez-faire approach to incorporating immigrants into Irish society. To offset some of the integration problems that have developed in other Western European countries that welcomed sizeable amounts of immigrants in earlier decades, this paper argues that Ireland's extensive history of emigration might be a useful tool to help the country include its increasingly large immigrant community because of the similar migration experience that both communities have encountered in their transnational pasts.

Keywords: emigration, immigration, social cohesion, history, memory

\section{Introduction}

'Due recognition is not just a courtesy we owe people, it is a vital human need.' - Charles Taylor

Despite not necessarily planning its current multicultural makeup, Ireland needs to acknowledge and include its immigrants in its society in order to reduce the chances of harmful social and ethnic divisions arising. Immigration has enormous implications for national culture and identity in the long term. But how can immigrants and Irish citizens identify with each other with seemingly contrasting histories and memories? This short paper argues that highlighting the common experience of migration that so many Irish born people and immigrants to Ireland have encountered may help to improve social cohesion if used in combination with other incorporation measures. By comparing immigrants in Ireland with Irish emigrants, people can place themselves in the shoes of recent newcomers, thereby bridging the cultural gap between the two groups and forming a potential common bond between them.

In order for readers to understand the centrality of emigration in Irish history, the first part of this paper will briefly set out the scale of outward movement that has taken since the nineteenth century. Critically, this section will also emphasise the transnational nature of Irish emigration - a characteristic rarely highlighted in the literature (Delaney 2011). The second part will focus on the enormous transition that Ireland has undergone in the last fifteen years, which has seen it transform from a country of sustained emigration to substantial immigration. Finally, arguments will be put forward to support the view that referencing Ireland's emigrant past does have the potential to help incorporate Ireland's sizeable immigrant population in the present and the future. 


\section{Emigration Past}

Approximately ten million people have emigrated from the island of Ireland since 1800 (Delaney 2002: 1). Considering the island's population today stands at roughly 6.3 million, the amount of people who have left the island is extraordinary compared to other European countries. At the centre of this massive emigration is the Great Irish Famine (1845-1852). Sizeable emigration did take place in the first half of the nineteenth century, but the scale of departure skyrocketed from the mid-1840s onwards with the onset of the Famine. During that disaster, over one million people died and around 1.25 million people fled the island (Smyth 2012: 4). As a result of death and emigration, the island's population dropped from a high of almost 8.5 million in the mid 1840s to 6.5 million in 1851 (Hatton and Williamson 1993: 575). The emigration of so many during the Famine led to the establishment of huge Irish communities abroad, particularly in the United States - the destination of choice for the vast majority. These vast networks helped to facilitate millions more Irish to emigrate in the decades following the Famine. No other European country contributed as many emigrants to the New World during the so-called 'age of mass migration' between the mid-nineteenth century and the start of the First World War - per capita as Ireland (Ó Gráda 1983: 118). At the turn of the twentieth century, over 2.5 million Irish-born people lived outside Ireland, at the same time as the island's population had decreased to less than 4.5 million (Delaney 2011: 601-2). Ireland's situation contrasted starkly with most other Western European countries, which saw their populations increase during the nineteenth and twentieth centuries in spite of emigration.

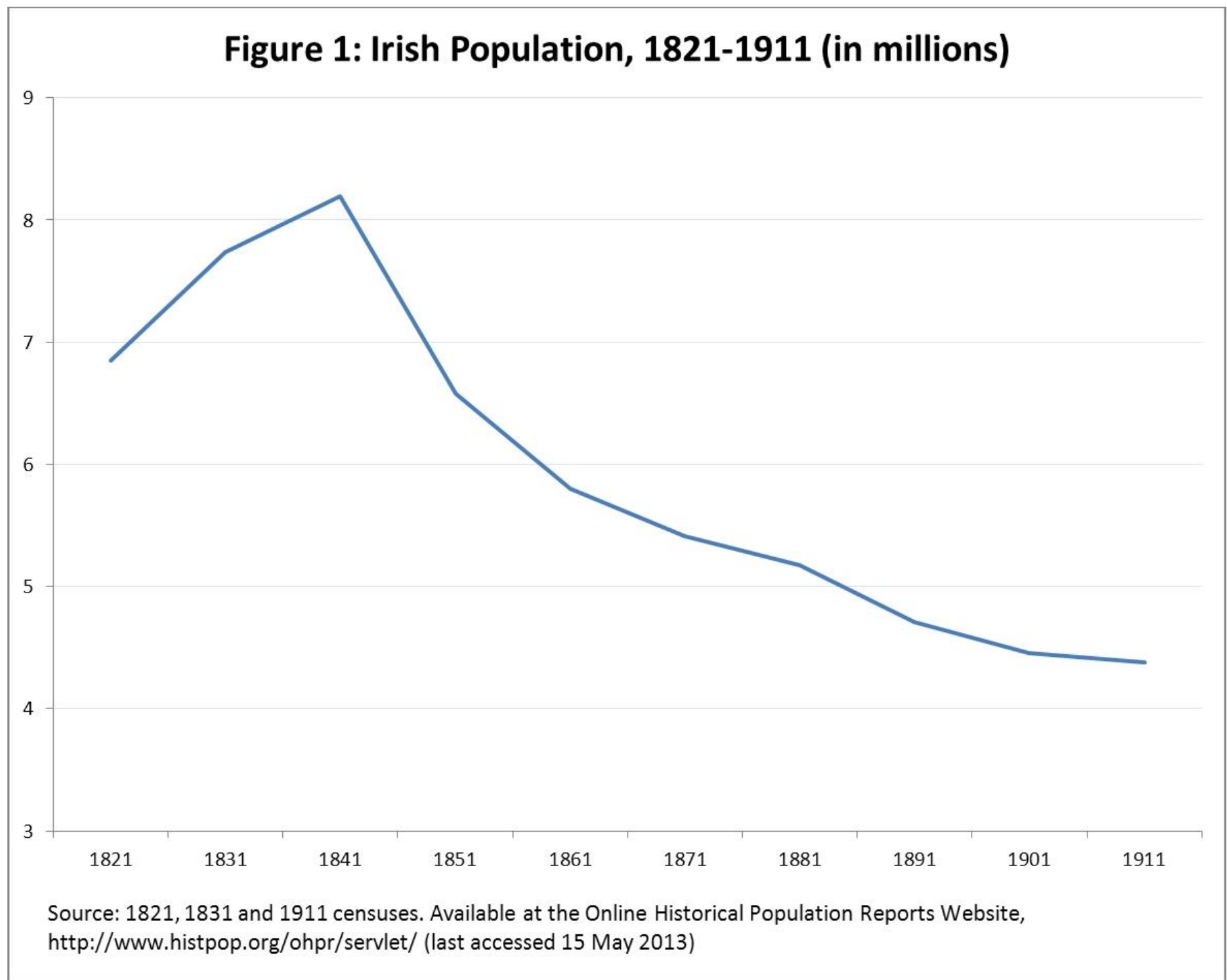

Figure1: Irish Population, 1821-1911

Despite most of the island gaining its independence in 1922, emigration continued - although most people went to England rather than America because of the immigration restrictions imposed across the Atlantic in the 1920s. 
During the Second World War, approximately 100,000 Irish moved to England. In the 1950s, around 400,000 (net) left the Irish Republic. Considering the country's population then stood at less than 3 million, to lose approximately 16 percent of your population in one decade - most of whom were young and left to gain employment abroad - was astonishing. Indeed, Ireland shared the ignominy of being the only country in Europe to see its population decline in the 1950s with East Germany (Daly 2006: 183). Although Italy, Spain and Greece also saw large swathes of their populations emigrate in the decades after the Second World War, no other European country experienced it on the same scale as occurred in Ireland during the 1950s - apart, perhaps from Portugal between 1969 and 1973 (Baganha 2003). Furthermore, none of these same countries experienced another exodus of its young people in the 1980s, as took place in Ireland on the back of renewed economic difficulties. In recent years - and especially since the economic crisis and subsequent bailout of Irish banks in 2009, emigration has again increased substantially in Ireland. The amount of Irish people leaving the country has more than tripled between 2008 and 2012, with no end yet in sight (CSO 2012b).

Many within Irish society have personal experience of migration. It was and is not only the Irish abroad who knew what it meant to leave one's country. Hundreds of thousands of Irish-born people chose to return for a variety of reasons. ' $t$ Hart (1985) estimates that 10 percent of Irish emigrants returned home in the nineteenth century. This conservative approximation would mean that as many as 800,000 Irish people returned to live in their country of birth in the 1800s. The percentage of emigrants that returned rose considerably in the twentieth century, when nearby England replaced the United States as the main destination. In the 1970s, for instance, return migration to the Republic of Ireland greatly outnumbered Irish emigration. Significantly, many return migrants brought home children born outside Ireland, as demonstrated by the enormous increase in Ireland's foreign-born population that took place between 1971 and 1981, which can be largely explained by the return of Irish families during this decade rather than the immigration of foreigners (see Figure 2).

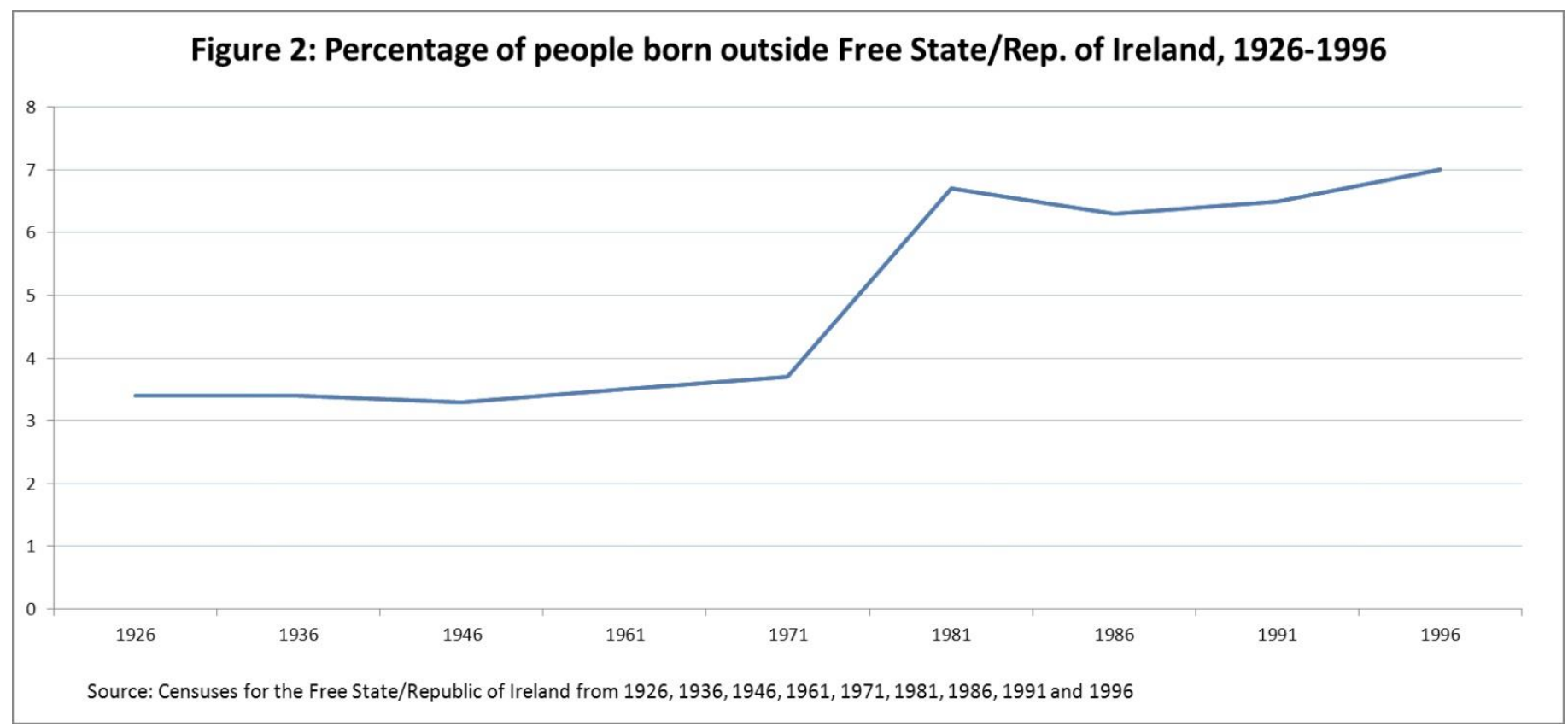

Figure 2: Percentage of people born outside the Free State, Rep. of Ireland, 1926-1996

Huge return migration also occurred during the so-called 'Celtic Tiger' era - although this time largescale immigration occurred simultaneously. In the 2011 census, just under 400,000 Irish-born people (CSO 2012a: 88) were recorded as having lived abroad continuously for over one year, which correlates to the UN definition of emigration (Figure 3 sets out when these people returned). 


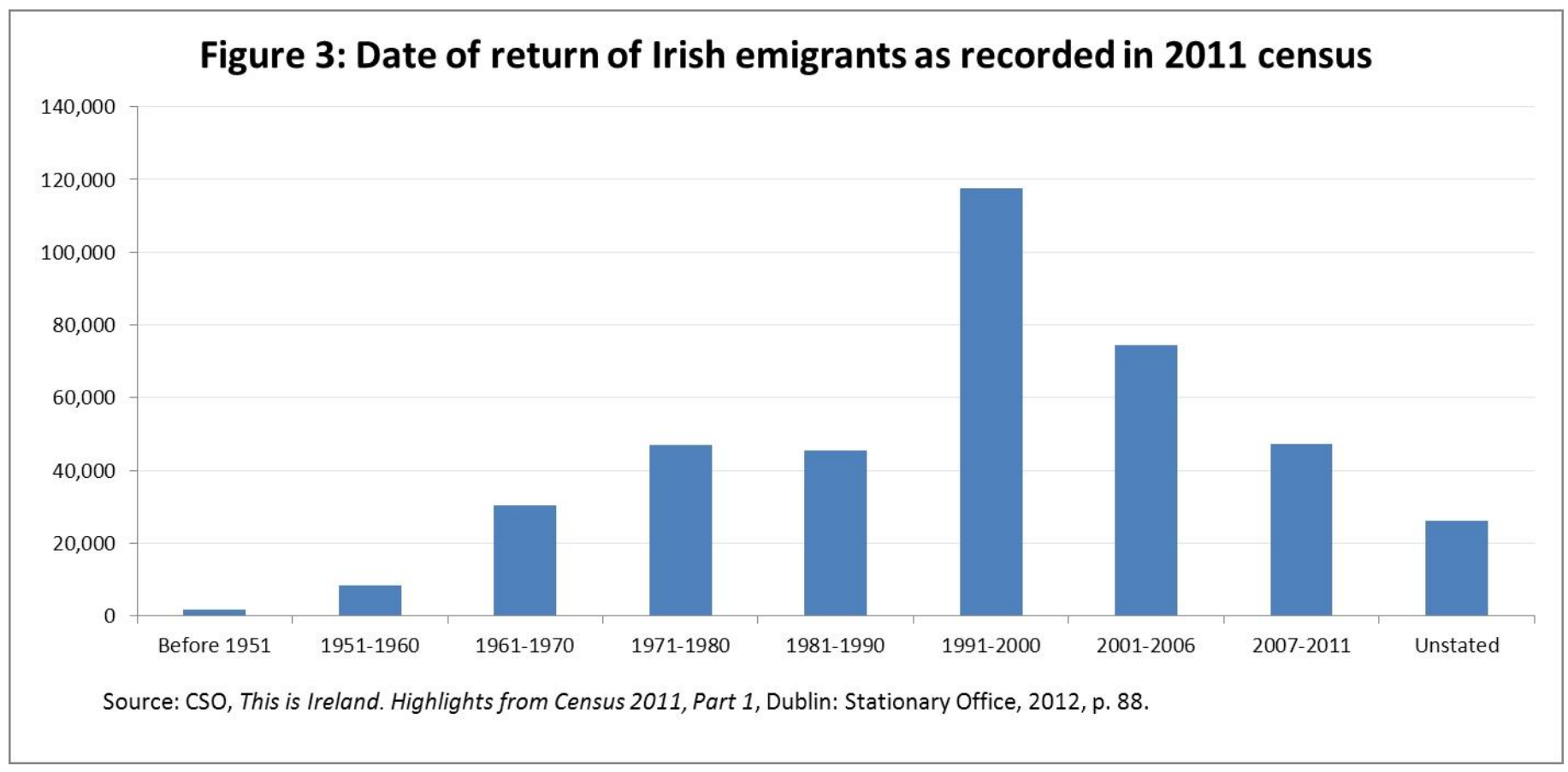

Figure 3: Date of return of Irish emigrants as recorded in 2011 census

Furthermore, almost 140,000 people living in the country with Irish nationality were born elsewhere, the majority of whom are presumed to be the children of returned emigrants (Gilmartin 2013: 4) Emigration, consequently, has had an enormous effect on Irish society over the last two centuries. It has touched almost every generation and still remains an emotive issue in Irish political debates. It is, therefore, an issue that many in Ireland can relate to because of its repeated centrality in Irish life.

\section{Immigration Present}

During the early 1990s, Ireland was the only country among the EU15 with a negative net migration rate (Ruhs 2009). From the mid 1990s onwards, however, Ireland experienced unprecedented immigration. Asylum applications first came to public prominence, when annual applications rose from 39 in 1992 to 3,883 by 1997, eventually peaking at 11,634 in 2002 (see figure 4). 


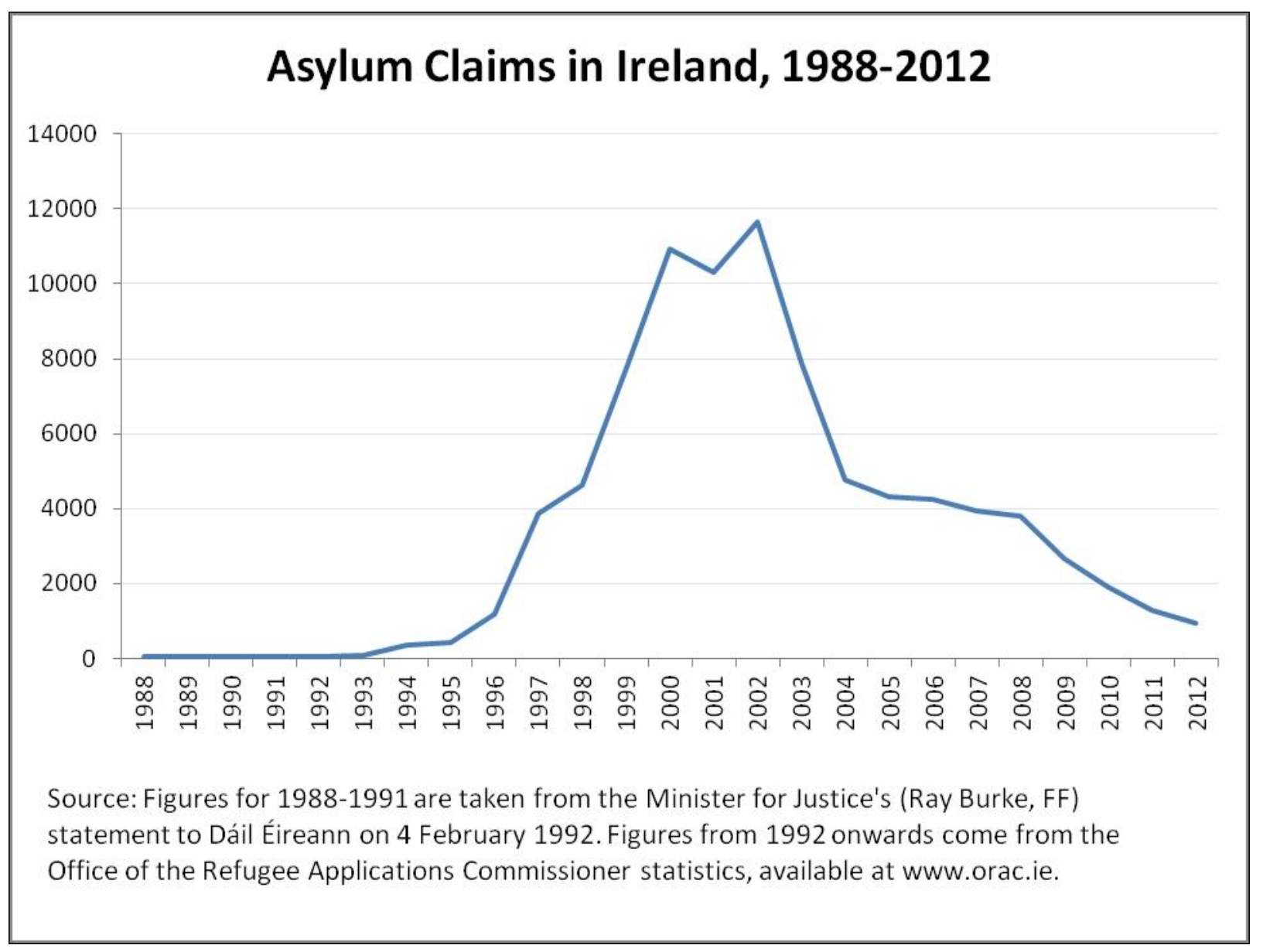

Figure 4: Asylum Claims in Ireland, 1988-2012

One journalist dramatically claimed that the country had not received such a large influx of immigrants seeking shelter since 'the Celts were driven west by the Romans' (Cullen 1997). Although asylum applications became the source of much political debate, labour migration had a much greater impact on the rising proportion of immigrants within the Irish population. By 2002, the share of immigrants in Ireland's population surpassed that of the UK and France, countries with much longer histories of immigration (Ruhs 2005: 10). Sustained economic growth during the 1990s and 2000s resulted in the amount of people in employment rising from approximately 1.5 million in 1996 to well over 2 million just ten years later (Bielenberg and Ryan 2012: 177).

Due to the perceived need for labour, Ireland, along with only two other 'old' EU15 member states, imposed no restrictions on people from the accession states entering its work market after the expansion of the EU in 2004. Whilst Sweden received extremely modest inward migration from accession states, the UK and especially Ireland played host to sustained and sizeable immigration from new EU states. Between 2004 and 2008, over half a million immigrants arrived in Ireland - the vast majority from new EU countries - to partake in the country's continued economic upsurge (CSO 2012b).

Immigration spanning little more than a decade transformed Ireland from a largely homogeneous Catholic society to an ethnically, racially and religiously diverse society. This rapid transformation was, according to Anthony Messina (2009: 14), 'virtually unprecedented in Western Europe'. Furthermore, in contrast to many other European states partly because of Ireland's role as a colony rather than a coloniser, immigrants in Ireland came from an enormous variety of countries and they settled all over the country and not just in Irish cities. Mac Éinrí and White noted in 2008 (161-2) that '[b]ehind a policy of vague respect for multicultural ideas there lurks a de facto assimilationism' in Ireland.

Much of the emphasis for the incorporation of newcomers into Irish society until then related to the perceived benefits that immigrants brought to the country's economy (NESC 2006: xii and Fanning 2011: 25). The collapse of Ireland's banking system from late 2008 onward, however, considerably altered the economic landscape. In a similar 
vein to what occurred with immigrants in Western European countries in the 1970s following the oil price shocks, most immigrants resident in Ireland have chosen to remain in the country despite the onset of severe economic recession. Indeed, immigrants have continued to arrive in Ireland, albeit in considerably lesser numbers than during the boom years. With a combined unemployment and underemployement rate of 23 percent in April 2013 (IMF 2013: 26), mounting public dissatisfaction with the state, and enormous national debts causing uncertainty about what the future holds, it is becoming increasingly difficult to associate the required incorporation of Ireland's immigrants with the country's economic requirements. As NESC (2006: 139) point out, 'host society attitudes towards non-nationals of different ethnic and cultural backgrounds can change under the influence of economic recession and international or domestic events that create new feelings of vulnerability'. How, then, does the Irish state plan to include its significant immigrant population into an Irish society with such huge economic problems?

'Integration' is an ambiguous concept that has been the source of much discussion. Gray (2006: 121-2), for example, validly argues that amalgamating immigrants with 'very different social, economic, political, cultural, gendered and racialised statuses and experiences' into one supposedly fixed group that need to be 'integrated' is questionable. Furthermore, as Gilligan (2006) notes, it is often difficult to grasp what immigrants should be 'integrated' into since national societies are so elusive and ambiguous. Nonetheless, it is still imperative to at least discuss what states can do in an attempt to help immigrants and citizens feel more comfortable in their ever-evolving, but shared, environment to offset tension developing between the two.

Immigration has yet to really feature in any political debates and immigrants remain invisible within mainstream Irish politics (Fanning 2012: 4). Considering the serious discussions that have taken place in most other Western European countries about how to adapt to their increasingly diverse societies, it is inevitable that Ireland will also one day be faced with such dilemmas. This paper suggests that Ireland's extensive history of emigration and return, set out briefly above, may help it to incorporate its immigrant population in the future.

\section{Diverse future}

Feelings of solidarity and support for other, often non-European, groups who were understood to have endured similar suffering to the Irish arose in the second half of the nineteenth century amongst many Irish nationalists (Lynch 2007). This led to the development of an 'open archive of suffering' (Glynn 2011), which facilitated calls for solidarity with peoples who were perceived to have experienced comparable fates. Throughout the twentieth century, Irish politicians repeatedly referenced the country's own colonial past to support Asian and African countries' determination to achieve independence, as exemplified by Frank Aiken, the Irish foreign minister, who spoke at the UN in 1957 about Ireland's 'memory which gives us a sense of brotherhood with the newly emerging peoples of today' (quoted in Gibbons 2001: 81).

Similar sentiments could be extended to immigrants living in Ireland since they bear many resemblances to Irish emigrants. Indeed, during the 150th anniversary commemorations of the Great Irish Famine in 1995, prominent public and political figures repeatedly compared Irish famine emigrants to migrants seeking asylum at the time in Ireland. Significantly, it influenced Ireland's first ever refugee debate, which saw politicians adapt a remarkably progressive stance, with every political party represented in parliament voicing its support for the formation of an expansive asylum policy (Glynn 2012). This marked a remarkable turnaround in Ireland's heretofore largely reprehensible treatment of asylum seekers since the 1930s (see Fanning 2002: 72-98 for details).

Despite Ireland undergoing an incredible transition in its demographic makeup in the years after the country's first refugee debate with the arrival of hundreds of thousands of immigrants, politicians and public figures made few notable references to Ireland's emigrant past when discussing immigration. Instead, economics and the needs of the Irish labour market featured prominently in the rare debates that took place on immigration and Ireland's rapidly diversifying population. At the same time, NGOs representing immigrants demanded better employee, family, 
citizenship and naturalisation rights. Unusually though, NGOs rarely compared the plight facing immigrants in Ireland to that encountered by Irish emigrants abroad.

Anti-immigration rhetoric often tries to draw attention to physical and cultural differences between certain immigrants and citizens. Emphasising similarities based on historical parallels, such as a common experience of migration, can negate these arguments somewhat and help people to identify with other each other. To achieve this, different people have to be able to relate to each other and, most importantly, empathise with one another. Gallinsky and Moskowitz (2000: 708) have observed that if people are instructed to place themselves in the same situation as others ('perspective-taking'), empathy can develop. Empathy, according to Stephan and Finlay (1999: 736), 'can be induced in several ways, take a variety of forms, and influence different aspects of intergroup relations'. If used effectively, it 'shows great promise of increasing the beneficial effects of intergroup relations programs' (Stephan and Finlay 1999: 741).

Every generation of Irish people in the last two centuries has had some experience of migration, whether it be their own migration abroad or that of family members and friends. Associating asylum seekers with former Irish emigrants in 1995 enabled Irish society to compare its migrant past with asylum seekers' migrant present, thereby bridging the cultural gap between the two groups and forming a potential common bond between them. Comparing immigrants to Irish citizens is not, of course, emblematic of avoiding the build-up of anti-migrant sentiments amongst politicians, the public and the media alike. Nonetheless, it is a useful tool to employ in immigration debates to counteract the rise of antipathy (an even stronger emotion than empathy) towards immigrants since perceived parallels can harbour feelings of solidarity and similitude between different groups. Banks (2008: 133) highlights the major problem that many states face today: they have 'to recognize and legitimize difference and yet construct an overarching national identity that incorporates the voices, experiences, and hopes of the diverse'. Linking Ireland's emigrant experience with its immigrant reality might help alleviate this problem and so needs to be explored further.

Baganha, M.I. 2003. Portuguese Emigration After World War II. In António Costa Pinto, ed., Contemporary Portugal, Politics, Society and Culture, New York: Boulder, pp.139-158.

Banks, J.A. 2008. Diversity, Group Identity, and Citizenship Education in a Global Age. Educational Researcher, 37 (3), pp.129-139.

Bielenberg, A. and Ryan, R. 2012. An Economic History of Ireland Since Independence, London: Routledge. CSO (Central Statistics Office) 2012a. This is Ireland. Highlights from Census 2011. Part 1, Dublin: CSO.

CSO 2012b. Population and Migration Estimates. Dublin/Cork: CSO.

Cullen, P. 1997. Only surprise is how long refugee influx has taken to happen here. Irish Times, 17 May.

Daly, M. 2006. Slow Failure. Population Decline and Independent Ireland, 1920-1973, Wisconsin: Wisconsin University Press.

Delaney, E. 2011. Our island story? Towards a transnational history of late modern Ireland. Irish Historical Studies, 37, No. 148 , pp.599-621.

Delaney, E. 2002. Irish Emigration since 1921, Dublin: ESHSI.

Fanning, B. 2012. Racism and Social Change in the Republic of Ireland, Manchester: Manchester University Press ( $2^{\text {nd }}$ ed).

Fanning, B. 2011. Immigration and social cohesion in the Republic of Ireland, Manchester: Manchester University Press.

Fanning, B. 2002. Racism and Social Change in the Republic of Ireland, Manchester: Manchester University Press. 
Galinsky, A. and Moskowitz, G. 2000. Perspective-Taking: Decreasing Stereotype Expression, Stereotype Accessibility, and In-Group Favoritism. Journal of Personality and Social Psychology, 78 (4), pp.708-724.

Gibbons, L. 2001. Guests of the Nation: Ireland, Immigration, and Post-Colonial Solidarity. In Meaghan Morris and Brett de Bary (eds.), Race Panic and the Memory of Migration, Aberdeen/Hong Kong: Hong Kong University Press, pp.79-102.

Gilligan, C. 2006. An Unsatisfactory Discussion of the Process of Ethnic Minority Integration in Ireland. Translocations, 1(1), pp.41-55.

Gilmartin, M. 2013. Changing Ireland, 2000-2012: immigration, emigration and inequality, Irish Geography.

Glynn, I. 2012. Famine commemorations and asylum debates in Ireland conflated. In Irial Glynn and J. Olaf Kleist, eds., History, Memory and Migration: Perceptions of the Past and the Politics of Incorporation, Basingstoke: Palgrave Macmillan, 173-188.

Glynn, I. 2011. Emigration histories and immigration realities in Ireland and Italy. In Bryan Fanning and Ronaldo Munck, eds., Globalization, Migration and Social Transformation. Ireland in Europe and the World, Hampshire: Ashgate, pp.65-77.

Gray, B. 2006. Migrant Integration Policy: A Nationalist Fantasy of Management and Control? Translocations, 1(1), pp.118-138.

Hatton, T. and Williamson, J. 1993. 'After the Famine: Emigration from Ireland, 1850-1913', Journal of Economic History, 53(3), pp.575-600.

IMF 2013. Ireland: Ninth Review under the Extended Arrangement, IMF Country Report No. 13/93.

Lynch, N. 2007, 'Defining Irish Nationalist Anti-Imperialism: Thomas Davis and John Mitchel' Éire-Ireland, 42 (1\&2), pp.82-107.

Mac Éinrí, P. and White, A. 2008. Immigration into the Republic of Ireland : a bibliography of recent research. Irish Geography, 41(2), pp.151-179.

Messina, A. 2009. The Politics of Migration to Western Europe: Ireland in Comparative Perspective. West European Politics, 32(1), pp.1-25.

NESC (National Economic and Social Council) 2006. Managing Migration in Ireland: A Social and Economic Analysis, Dublin: Stationery Office.

Ó Gráda, C. 1983. Across the Briny Ocean: Some Thoughts on Irish emigration to America, 1800-1850. In Thomas Devine et al., eds., Ireland and Scotland, 1600 1850, Edinburgh, 118-130.

Ruhs, M. 2009. Ireland: From Rapid Immigration to Recession', Migration Information Source. Available online at http://www.migrationinformation.org/Profiles/display.cfm?ID=740 (last accessed 15 May 2013).

\section{Biographical Note:}

Irial Glynn specialises in migration history. He co-edited, with J. Olaf Kleist, History, Memory and Migration: Perceptions of the Past and the Politics of Incorporation for Palgrave Macmillan (2012) and has recently written articles about the 1951 Refugee Convention in the Journal of Refugee Studies and the treatment of migrants in Europe during economic crises in Comparative Population Studies. Irial obtained his Ph.D. from the European University Institute, Florence, and has held visiting fellowships at the University of Oxford and New York University. He is currently a postdoctoal researcher in the Department of Geography and the ISS21 in University College Cork for the EMIGRE project, which is examining contemporary Irish emigration. 
irial.glynn@gmail.com. 